\title{
Information and communication technology reading interventions: $A$ scoping review
}

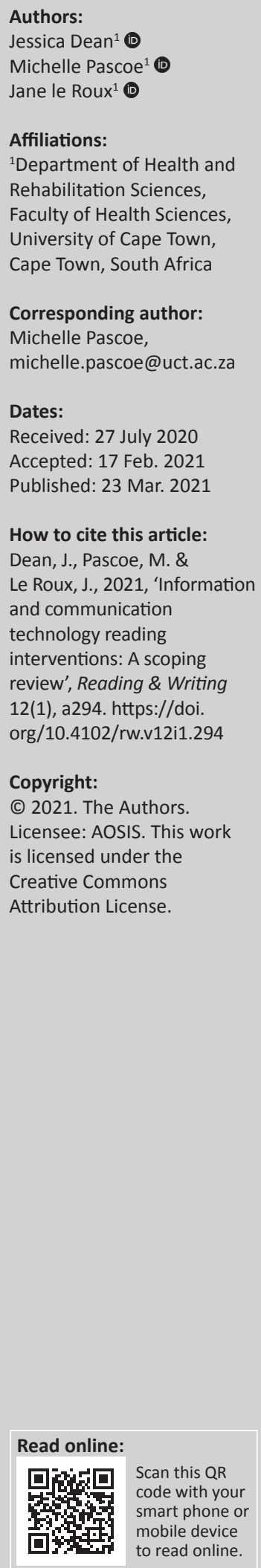

Authors:

essica Dean

Affiliations:

Department of Health and Faculty of Health Sciences,

University of Cape Town

Michelle Pascoe,

Dates:

Accepted: 17 Feb. 2021

How to cite this article:

Dean, J., Pascoe, M. \&

and communication

technology reading

interventions: A scoping

org/10.4102/rw.v12i1.294

Copyright:

Licensee: AOSIS. This work

is licensed under the

Creative Commons
Background: Information and communication technology (ICT) reading interventions can help children with reading difficulties, especially those in resource-constrained environments who otherwise might not have support.

Objectives: (1) Provide an overview of ICT reading interventions used globally with primary school children. (2) Provide further information on the subset of studies conducted in majority world countries, describing the interventions used, their impact on reading and challenges faced.

Method: A scoping review was used with a search strategy that yielded a total of 49 studies for inclusion in the main review (Objective 1), and a subset of five studies undertaken in the majority world (Objective 2).

Results: Most published studies (93.88\%, 46 studies) demonstrated positive outcomes of ICT reading interventions on learners' reading. Well-researched programmes with demonstrated effectiveness included GraphoGame, ABRACADABRA, Reading RACES and Chassymo. Only five studies $(10.2 \%)$ were conducted in the majority world, but all reported in this subset described positive literacy gains through ABRACADABRA and GraphoGame.

Conclusion: There is a growing evidence base of ICT reading interventions that could be helpful in addressing the reading crisis in South Africa. Programmes such as ABRACADABRA and GraphoGame demonstrate effectiveness in a variety of contexts and may have a role to play in addressing the reading challenges faced by children in South Africa.

Contribution: The review highlighted evidence supporting the use of ICT reading interventions. Evidence of such approaches in South Africa (and other majority world countries) remains limited and requires further evaluation of both existing and innovative, locally developed interventions.

Keywords: reading interventions; ICT; computer-based; applications; effectiveness.

\section{Introduction}

The majority of South African learners are not developing the reading skills expected for each grade when compared to their international peers (Department of Basic Education 2014; Mullis et al. 2017). This is a multifaceted problem linked to a complex interplay of educational, political, social and economic factors described by authors such as Spaull (2013). Factors related to learners' underperformance include resource constraints, inadequate teacher training, poor instructional practices, low parental literacy levels, learning in a second or additional language, and high rates of absenteeism (Howie et al. 2017). Multifaceted interventions that focus on a range of aspects such as infrastructure, teacher training and classroom interventions are necessary to address the situation and bring about a more positive outlook.

In this article we focus specifically on interventions for learners with reading difficulties, based on our backgrounds as speech-language therapists (SLTs) working to support learners with literacy and language challenges. Speech-language therapists play an important role in promoting the communication and literacy development of children and providing evidence-based intervention to at-risk individuals. However, SLTs comprise a small professional group in South Africa, culturally and linguistically appropriate resources are scarce, and most SLTs working in the public sector are employed by health rather than education departments. There is thus an urgent need for innovative approaches to help SLTs increase their reach (Nadler-Nir \& Pascoe 2016).

Large-scale, population-based interventions are required to target reading in South African schools. In their evidence-based profession, it is important for SLTs to know which interventions 
have demonstrated effectiveness, as well as to expand the evidence base through ongoing intervention studies.

Reading intervention research shows that targeting phonological awareness, phonics, fluency, vocabulary and reading comprehension in an explicit, intensive and systematic manner improves reading skills (Galuschka et al. 2014; Gibson \& Musti-Rao 2017; National Reading Panel 2000; Suggate 2016). Despite this knowledge, serving the large population of children requiring reading intervention is a challenge, especially in resource-constrained contexts. One approach to providing reading support is through the use of information and communication technology (ICT) programmes. There is a wide range of technology-based tools available to help children develop their reading, spelling and language abilities. These vary in terms of the ages targeted, their specific focus, platforms used, accessibility and cost. Although not all studies investigating the impact of ICT-based approaches to reading have reported positive outcomes (Campuzano et al. 2009), reviews and meta-analyses indicate that many ICT programmes produce gains in phonological awareness, phonics, word reading, fluency, vocabulary and reading comprehension of schoolaged children (Cheung \& Slavin 2011, 2013; Jamshidifarsani et al.2019; Moran et al.2008). Information and communication technology-based reading intervention holds potential for improving the reading skills of children by harnessing their motivation to learn through feelings of autonomy (making choices), competence (achieving goals), and relatedness (sharing experiences with another individual), providing immediate feedback and having the capacity to be intensive, individualised, and at the appropriate level of difficulty, and enabling independent use or the presence of nonprofessionals (McTigue \& Uppstad 2018).

In this scoping review we set out to describe ICT interventions for reading and their outcomes as described in the literature. A particular aim of the study was to consider interventions developed for, or investigated in the majority world (developing) contexts which might offer solutions to the challenges faced in South Africa.

The objectives of the study were to: (1) provide an overview of ICT-based reading interventions described in the literature over the last decade (2009-2019) and (2) consider the subset of ICT reading interventions conducted in the majority world and their impact on learners' reading skills and challenges faced, which could lead to recommendations for research conducted in similar contexts, such as South Africa.

\section{Methodology}

Scoping reviews are used to map the main sources and types of evidence available, and are particularly useful when an area is complex or has not been reviewed comprehensively before. Arksey and O'Malley's (2005) framework has five steps: (1) identifying the research question or aim. This review set out to describe ICT reading interventions for primary school learners undertaken in the last decade.
In particular we wanted to know what work has been undertaken in the majority world so that we could investigate programmes reported to be effective in this context and build on them further. (2) Identifying and (3) selecting relevant studies. A search strategy, criteria for eligibility and study selection were devised, and are described in the following sections. (4) Data are then charted, collated and (5) reported in the results section of the article. The search took place between June 2018 and June 2019, undertaken mainly by the first author with the other two authors in a checking and support role. To ensure a valid and reliable process, measures were put in place such as team briefings on a regular basis to discuss any uncertainties regarding the process and findings to date.

\section{Search strategy}

First, a pilot phase was initiated in which one database was searched using a set of core terms. Titles, keywords and index terms taken from this initial set of papers were then used to develop the list of search terms further. Second, following the pilot phase, researchers then used the complete search term list with the full set of electronic databases. Keywords were entered into the electronic databases of PsycArticles, PsychINFO, ERIC, Computers and Applied Sciences Complete, Academic Search Premier and CINAHL.

The keywords were: information and communication technology; computer-assisted; computer-based; laptop; smartphone; iPhone; tablet; iPad; application; programme; software; reading intervention; reading instruction; reading therapy; reading remedial; primary school; elementary school; middle school; junior school; children and learners.

\section{Eligibility criteria}

Studies were included in the review based on the following inclusion criteria:

- Published in a peer-reviewed journal between 2009 and 2019.

- Interventions described needed to be delivered by ICT, and aimed at improving reading or reading-related skills (one or more of the components of phonological awareness, letter-sound knowledge or phonics, word reading, fluency, vocabulary and reading comprehension).

- Learners in Grades 1 to 7 were the participants.

- Experimental or quasi-experimental designs were used, that is, the included studies all considered the effect of an intervention on particular outcomes; control groups were used, although in the case of a quasi-experimental design assignment into the groups was not random.

Due to time and resource constraints we were only able to access and review papers in English, and grey literature (e.g. postgraduate student projects, government reports) was not searched. Meta-analyses, reviews and editorial or discussion pieces were excluded. We wanted to access original research papers that might have contributed to a 
meta-analysis or review, or informed a discussion piece. We aimed to access original research where full methodological information and results could be accessed. Titles and abstracts of papers generated by the search were reviewed by the team.

\section{Study selection}

The first author screened the titles and abstracts of the articles from the electronic search, and then read full texts of all papers that met the eligibility criteria. Papers were excluded when the eligibility criteria were not met. If a full-text article could not be accessed, it was automatically excluded from the database. A total of 49 studies met the inclusion criteria and were subsequently included in the review.

\section{Data collection}

After identification of relevant papers, full-text articles were read and data extracted from them. Detailed information about resources was charted in a spreadsheet including the name of the paper, authors, journal, country in which the study took place, research design, number and nature of participants, the name or description of intervention, devices used, outcomes measured, person supporting the intervention, and summary of outcomes. To ensure reliable reporting, the second and third authors cross-checked a proportion $(20 \%)$ of all entries into the database.

\section{Results}

\section{Overview of ICT-based reading interventions described in the literature}

In the 49 papers included in this part of the study, the most commonly used design was an experimental pre-post design with random assignment to groups at the level of schools, classes or learners (23 studies; 46.94\%) and experimental multiple baseline design across participants (10 studies; $20.4 \%)$. There were $27(55.1 \%)$ studies where ICT interventions were compared to a control group receiving no intervention and $16(32.65 \%)$ studies that evaluated ICT interventions against other interventions. Sample sizes varied widely with most studies $(29 / 49,59.2 \%)$ having fewer than 100 participants. Of the studies that described the grade of the participants, most focused on children in Grades 1 to 3. Most $(40 / 49 ; 81.6 \%)$ had both male and female participants. The studies included learners with different characteristics such as: at risk of having reading difficulties (7; 14.29\%), reading difficulties $(26 ; 53.1 \%)$, language difficulties $(3 ; 6.12 \%)$, and learners from mainstream schools not included based on any identified difficulties $(13 ; 26.53 \%)$. Five studies included learners with additional difficulties (such as intellectual disability, attention deficit and hyperactivity disorder, autism spectrum disorder and learning disability). Of the studies that reported the language characteristics of the participants, 29 investigated monolingual children, 9 involved bilingual children and 4 worked with bi- and monolingual children. Many studies did not report on the languages of the participants.
A total of 46 different ICT reading interventions were described. Some studies evaluated one programme while others used two or more, comparing outcomes between groups. Programmes used in more than two studies included GraphoGame/GraphoLearn (henceforth GraphoGame) (used in 10 papers), ABRACADABRA (6 papers), Reading RACES (3 papers) and Chassymo (3 papers). These 'big four' programmes thus dominated the literature for the time period investigated. GraphoGame targets multiple levels of reading (phonics and letter-sound knowledge, phonological awareness and word reading). It is a theoretically informed intervention that has been well researched over many years and adapted for use in a variety of different languages. The programme is available to all school-aged children in Finland, and in many other countries around the world in adapted forms (see Ojanen et al. 2015 for further information).

ABRACADABRA similarly targets a range of skills including phonics and letter-sound knowledge, word reading, reading and listening comprehension, reading fluency and metacognition in reading and writing. It was developed in Canada and has been extensively used there as well as in Australia. It is based on the recommendations of the National Reading Panel (2000) and includes a variety of different activities tailored to children's specific abilities and challenges. Reading RACES focuses on oral reading fluency through a repeated reading strategy using culturally relevant stories for primary school children. Chassymo, developed in French, focuses on the syllable as the main processing unit in reading and requires learners to hear or read syllables in a carefully programmed presentation. Most of the other interventions targeted two or more skills, such as reading fluency and comprehension (e.g. Bennett et al. 2017) while a smaller number focused solely on one particular skill such as sightword reading (e.g. Musti-Rao, Lo \& Plati 2015), or reading comprehension (e.g. Ponce, López \& Mayer 2012).

Interventions were delivered in various languages, although English dominated (30 studies, 61.22\%). Of the studies that described the language background of the learners, there were 30 where the intervention was in the participants' home language, 6 where the intervention was in the participants' second language, 2 where the intervention was in the first and second language and 4 where the language of intervention was some participants' home language but other participants' second language. A total of 18 different countries were represented. Almost half of the papers were from US-based studies (21 papers) and other countries that were well represented included France (4), England (3), Sweden (3), and Canada (3).

The devices used to deliver intervention mainly included computers $(35 ; 71.42 \%)$ and iPads or tablets $(10 ; 20.4 \%)$. There was a balance between studies that required facilitation $(25 ; 51.02 \%)$ and those in which learners worked independently $(22 ; 44.89 \%)$. When intervention was facilitated this was most typically done by trained teachers. Intervention intensity varied across studies with reported 
total intervention time ranging from $50 \mathrm{~min}$ to $109 \mathrm{~h}$. The mean length of total intervention time was $16 \mathrm{~h}$ typically undertaken in half-hour blocks delivered two to three times per week. Most studies (29, 59.18\%) used standardised outcome measures. Some used non-standardised outcome measures $(13,26.5 \%)$ and the remainder used a combination of both standardised and non-standardised outcome measures. The number of studies that found intervention effects for their outcome measures was calculated. There were three studies that did not demonstrate effects on any outcome measures, nine that demonstrated effects on $15 \%$ $50 \%$ of outcome measures, five that showed effects on $60 \%-$ $75 \%$ of outcome measures and 27 that showed effects on all outcome measures. There were five studies where the findings could not be categorised into these groups.
Therefore, of the studies that could be clustered into these groups, the vast majority $(41 / 44 ; 93.18 \%)$ demonstrated some form of positive effect of ICT reading intervention on learners' reading and reading-related skills and most $(32 / 44 ; 72.73 \%)$ showed improvements on $60 \%-100 \%$ of outcome measures. Table 1 shows a mapping of the 49 papers to give an overview of the designs used, sample sizes and participants, intervention and outcomes. Further detail for each of the 49 papers is provided in the appendices (Tables 1-A1-3-A1).

Results from the first part of the study indicated a substantial number of ICT interventions for reading that have been researched and published in peer-reviewed journals over the past decade. Most of the programmes demonstrated positive

TABLE 1: Design and participant characteristics of studies included in the information and communication technology-based reading intervention scoping review.

\begin{tabular}{|c|c|c|c|c|}
\hline \multicolumn{2}{|c|}{ Design and participant characteristics } & \multicolumn{2}{|c|}{$\begin{array}{l}\text { Number } \\
\text { of studies }\end{array}$} & \multirow[t]{2}{*}{ Examples } \\
\hline & & $n$ & $\%$ & \\
\hline \multirow[t]{3}{*}{ Study design } & $\begin{array}{l}\text { Experimental pre-post with random } \\
\text { assignment }\end{array}$ & 23 & 46.94 & $\begin{array}{l}\text { O'Brien, Begum and Onnis (2019); Messer and Nash (2018); Patel et al. (2018); Solheim et al. } \\
\text { (2018); Baker et al. (2017). }\end{array}$ \\
\hline & $\begin{array}{l}\text { Experimental multiple baseline across } \\
\text { participants }\end{array}$ & 10 & 20.41 & $\begin{array}{l}\text { Council et al. (2019); Mize et al. (2019); Barber et al. (2018); Musti-Rao et al. (2015); Lindeblad } \\
\text { et al. (2016); Ozbek and Girli (2017). }\end{array}$ \\
\hline & $\begin{array}{l}\text { Other experimental design or } \\
\text { quasi-experimental }\end{array}$ & 16 & 32.65 & Lysenko et al. (2019); Kleinsz et al. (2017); Mak et al. (2017); Moser, Morrison and Wilcox (2017) \\
\hline \multirow[t]{5}{*}{ Sample sizes } & $0-49$ & 23 & 46.94 & Council et al. (2019); Mize et al. (2019); Barber et al. (2018); Patel et al. (2018). \\
\hline & $50-99$ & 6 & 12.24 & Messer and Nash (2018); Baker et al. (2017); Van de Ven et al. (2017); Tyler et al. (2015). \\
\hline & 100-499 & 14 & 28.57 & O’Brien et al. (2019); Mak et al. (2017); Abrami et al. (2016); Schneider et al. (2016). \\
\hline & 500-999 & 4 & 8.16 & Solheim et al. (2018); Madden and Slavin (2017); Jere-Folotiya et al. (2014). \\
\hline & $1000+$ & 2 & 4.08 & Lysenko et al. (2019); Ponce et al. (2012). \\
\hline \multirow{4}{*}{$\begin{array}{l}\text { Participant } \\
\text { grades }\end{array}$} & Grade 1 & 14 & 28.57 & Barber et al. (2018); Solheim et al. (2018); Baker et al. (2017); Musti-Rao et al. (2015). \\
\hline & Grade 2 & 10 & 20.41 & Council et al. (2019); Bennett et al. (2017); Kleinsz et al. (2017); Schneider et al. (2016). \\
\hline & Grade 3 upwards & 6 & 12.24 & Mize et al. (2019); Patel et al. (2018); Moser et al. (2017); El Zein et al. (2016). \\
\hline & Mixed or not indicated & 19 & 38.77 & Lysenko et al. (2019); O’Brien et al. (2019); Madden and Slavin (2017). \\
\hline \multirow[t]{10}{*}{ Intervention } & GraphoGame & 10 & 20.41 & $\begin{array}{l}\text { O’Brien et al. (2019); Patel et al. (2018); Solheim et al. (2018); Baker et al. (2017); } \\
\text { Kamykowska et al. (2014); Kyle et al. (2013). }\end{array}$ \\
\hline & ABRACADABRA & 6 & 12.24 & $\begin{array}{l}\text { Lysenko et al. (2019); Mak et al. (2017); Abrami et al. (2016); Lysenko and Abrami (2014); } \\
\text { Savage et al. (2010). }\end{array}$ \\
\hline & Reading Races & 3 & 6.12 & Council et al. (2019); Barber et al. (2018); Bennett et al. (2017). \\
\hline & Chassymo & 3 & 6.12 & Kleinsz et al. (2017); Ecalle, Kleinsz and Magnan (2013) \\
\hline & LoCo Text & 2 & 4.08 & Kleinsz et al. (2017); Potocki, Ecalle and Magnan (2013) \\
\hline & Read 180 & 2 & 4.08 & Kim et al. 2010, 2011. \\
\hline & Tutoring with Alphie & 2 & 4.08 & Madden and Slavin (2017); Chambers et al. (2011). \\
\hline & Omega-interactive sentences & 2 & 4.08 & Fälth et al. (2013); Gustafson et al. (2011). \\
\hline & COMputerized PHOnological Training & 2 & 4.08 & Fälth et al. (2013); Gustafson et al. (2011); Mize et al. (2019); Messer and Nash (2018); Horne \\
\hline & Other & 17 & 34.69 & \\
\hline \multirow[t]{4}{*}{ Facilitation } & None/independent & 22 & 44.90 & O’Brien et al. (2019); Barber et al. (2018); Messer and Nash (2018). \\
\hline & Adult supported & 24 & 48.98 & $\begin{array}{l}\text { Lysenko et al. (2019); Council et al. (2019); Bennett et al. (2017); Madden and Slavin (2017); } \\
\text { Larabee, Burns and McComas (2014). }\end{array}$ \\
\hline & Peer supported & 1 & 2.04 & Mize et al. (2019); Chambers et al. (2011). \\
\hline & Mix of different supports & 2 & 4.08 & \\
\hline \multirow{5}{*}{$\begin{array}{l}\text { Total } \\
\text { intervention } \\
\text { time }\end{array}$} & Up to $4 \mathrm{~h}$ & 8 & 16.33 & Mize et al. (2019). \\
\hline & $5 h-25 h$ & 14 & 28.57 & Kleinsz et al. (2017); Ecalle et al. (2013); Fälth et al. (2013); Kyle et al. (2013). \\
\hline & $26 \mathrm{~h}-50 \mathrm{~h}$ & 3 & 6.12 & Lysenko et al. (2019). \\
\hline & More than $50 \mathrm{~h}$ & 5 & 10.20 & Saine et al. (2011); Torgesen et al. (2010). \\
\hline & Not reported & 19 & 38.70 & Mak et al. (2017); Schneider et al. (2016). \\
\hline \multirow{3}{*}{$\begin{array}{l}\text { Outcomes } \\
\text { measures found } \\
\text { to have } \\
\text { changed } \\
\text { significantly as } \\
\text { a result of } \\
\text { intervention }\end{array}$} & $\begin{array}{l}\text { No outcomes measures shown to have } \\
\text { changed; no intervention effect }\end{array}$ & 3 & 6.12 & Baker et al. (2017); Moser et al. (2017); Kamykowska et al. (2014). \\
\hline & $\begin{array}{l}\text { All outcomes measures changed; } \\
\text { positive intervention effect }\end{array}$ & 27 & 55.10 & $\begin{array}{l}\text { Council et al. (2019); Lysenko et al. (2019); Mize et al. (2019); O'Brien et al. (2019); Barber et al. } \\
\text { (2018); Messer and Nash (2018); Solheim et al. (2018); Bennett et al. (2017); Kleinsz et al. } \\
\text { (2017); Madden and Slavin (2017); Lindeblad et al. (2016). }\end{array}$ \\
\hline & $\begin{array}{l}\text { Mixed outcomes: Some show no change } \\
\text { and others indicate positive effect }\end{array}$ & 19 & 38.70 & $\begin{array}{l}\text { Patel et al. (2018); Horne (2017); Mak et al. (2017); Abrami et al. (2016); Schneider et al. (2016); } \\
\text { Musti-Rao et al. (2015); Larabee et al. (2014). }\end{array}$ \\
\hline
\end{tabular}

Note: Please see the full reference list of this article, Dean, J., Pascoe, M. \& Le Roux, J., 2021, 'Information and communication technology reading interventions: A scoping review', Reading \& Writing 12(1), a294. https://doi.org/10.4102/rw.v12i1.294, for more information. 
effects on children's literacy and language, despite variation in the nature and duration of the programmes. A small set of programmes (GraphoGame, ABRACADABRA, Reading RACES, and Chassymo) appeared in multiple studies and seem to have been most rigorously investigated in the 10-year period to demonstrate their effectiveness in different contexts. Given our specific context and challenges in South Africa, the second part of the review focused on a subset of studies from the main scoping review, ICT interventions undertaken in majority world countries, which we considered might be especially applicable to children in South Africa.

\section{ICT reading interventions conducted in the majority world and their impact on learners' reading skills}

In the main data set we found five studies conducted in the majority world: two in Kenya, and one in each of Zambia, India and Tanzania, constituting $10.2 \%$ of the total number of papers found in the review. These five studies used two interventions from the 'big four' group introduced in the previous section: ABRACADABRA and GraphoGame. All studies conducted in the majority world demonstrated improvements in learners' reading skills as a result of the ICT intervention. Two of the studies found positive intervention effects on all outcome measures and three noted positive intervention effects on at least half of their outcome measures. Table 2 provides an overview of these studies.

Lysenko et al. (2019) conducted a study in Kenya that examined the effect of English $A B R A C A D A B R A$ intervention (targeting phonological awareness, phonics, word reading, fluency, vocabulary, listening comprehension, reading comprehension and writing) and READS intervention (online stories and books available in English and Kiswahili to improve reading fluency and comprehension) on English literacy skills. A quasi-experimental design was used with a large sample $(n=1672)$ of Grade $1-3$ children learning English as a second language in mainstream schools. Schools were non-randomly assigned to ICT intervention or control conditions. Trained teachers facilitated intervention for a total of $2 \mathrm{~h}$ per week for a total of 16 weeks. Standardised assessments of English oral language and reading skills as well as participants' national examination results (in English, Social Studies, Mathematics and Science) were used as outcome measures. The results showed that intervention participants significantly outperformed control participants on all measures. Another study using $A B R A C A D A B R A$ was undertaken by Abrami et al. (2016) in Kenya to investigate the impact of English $A B R A C A D A B R A$ intervention on mainstream Grade 2 children $(n=354)$ learning English as a second language. An experimental pre-test-post-test design with random assignment of classes to conditions (intervention versus no intervention or control) was used.

Intervention participants made significant gains in reading comprehension and listening comprehension compared to the control group and participants in the intervention group significantly outperformed children in the control group in the national examinations.

Ngorosho (2018) conducted a study in Tanzania that investigated the impact of Kiswahili GraphoGame (targeting phonological awareness, phonics and word reading) on Kiswahili literacy skills. An alternating treatment design with random assignment of schools to groups (ICT intervention versus non-ICT classroom intervention versus no intervention or control) was used. Participants were Kiswahili home language Grade 1 learners $(n=49)$ with poor reading skills. Participants accessed GraphoGame via smartphones and worked independently (without adults being involved in instruction) for three sessions per day, 10 min per session, 5 days a week (a total of $2-4 \mathrm{~h}$ of intervention). Non-standardised outcome measures were used. The findings indicated significant improvements for both the ICT and non-ICT classroom intervention, although the ICT intervention led to the greatest improvement. Jere-Folotiya et al. (2014) conducted a study in Zambia to determine the effect of ciNyanja GraphoGame on mainstream Grade $1(n=573)$ children's ciNyanja literacy skills. As for the Tanzanian study, learners accessed intervention independently on smartphones 3-5 days per week (for six sessions which were 7-9 $\mathrm{min}$ long per day) for a total of $1 \mathrm{~h}$ and $34 \mathrm{~min}$ of intervention. Standardised measures of orthographic awareness and spelling acted as outcome measures. The results showed that the intervention improved the spelling (intervention participants significantly outperformed control participants) but not the orthographic awareness of participants. The learners who were exposed to intervention directly (played GraphoGame) and indirectly (teacher played GraphoGame) produced significant improvements in spelling compared to control learners.

Patel et al. (2018) conducted a study in India using an experimental pre-test-post-test design with random

TABLE 2: Information and communication technology studies carried out in the majority world - An overview based on a subset of the main scoping review.

\begin{tabular}{llcccc}
\hline & Design & & \multicolumn{3}{c}{ Participant characteristics } \\
\cline { 3 - 6 } & & $\boldsymbol{n}$ & Grade & $\begin{array}{c}\text { Age } \\
\text { (years) }\end{array}$ & Selection criteria for inclusion \\
\hline Lysenko et al. (2019) & Two-group, non-equivalent, pre-test-post-test quasi-experiment & 1672 & $1-3$ & - & Mainstream learners \\
Ngorosho (2018) & Alternating treatment & 49 & 1 & $7-9$ & Poor reading and spelling skills \\
Patel et al. (2018) & Pre-test and post-test, random assignment to groups & 30 & 3 & $7-8$ & Reading difficulties, English second language learners \\
Abrami et al. (2016) & Pre-test and post-test (random assignment to intervention and control groups) & 354 & 2 & - & Mainstream learners \\
Jere-Folotiya et al. (2014) & Pre-test and post-test (random assignment to intervention and control groups) & 573 & 1 & $5-9$ & Mainstream learners \\
\hline
\end{tabular}

Note: Please see the full reference list of this article, Dean, J., Pascoe, M. \& Le Roux, J., 2021, 'Information and communication technology reading interventions: A scoping review', Reading \& Writing 12(1), a294. https://doi.org/10.4102/rw.v12i1.294, for more information. 
assignment to conditions (ICT reading intervention versus an ICT Mathematics intervention control). Grade 3 learners $(n=30)$ with reading difficulties who did not have English as a home language but were attending a school where English was the medium of instruction participated. Intervention participants used English GraphoGame (to improve phonological awareness, phonics and word reading) independently on tablets for 8 weeks (20-30 min per session and six sessions per week). Non-standardised (informal ingame assessments) and standardised literacy assessments were used as outcome measures. Significant improvements in favour of the intervention group were found for all GraphoGame in-game measures but there was no difference between the improvements of the intervention and control groups on the standardised measures. These interventions are summarised in Table 3.

The five studies conducted in the majority world (Abrami et al. 2016; Jere-Folotiya et al. 2014; Lysenko et al. 2019; Ngorosho 2018; Patel et al. 2018) reported a range of study-related challenges: learners had limited exposure to technology before beginning the intervention, high rates of learner absenteeism, learners arriving at school late, finding time for supplemental ICT intervention in a curriculum-determined timetable, lack of linguistically and culturally appropriate assessment measures (and lack of standardisation of assessments on the study population), technological issues, and venue constraints (no quiet venues at schools where intervention and assessments could be conducted). They reported the following contextual challenges: poor infrastructure, shortage of reading and teaching materials, poor working conditions for teachers, teachers inadequately trained for literacy instruction, poor teaching methods (rote learning), learners not being exposed to the language of learning and teaching in the home environment, parents having low literacy levels or being illiterate, and lack of learner exposure to literacy activities in the home environment.

\section{Discussion}

Research conducted in the last decade suggests that ICT approaches to reading intervention can lead to improvements in learners' reading skills, and thus offers potential for providing support to large numbers of children who require it - especially in places such as South Africa which has an acknowledged literacy crisis (Spaull 2013). There were only four studies in the scoping review that were conducted in Africa and none of these was conducted in South Africa. However, the small subset of papers from the majority world tentatively suggest that ICT-based approaches to reading intervention may be helpful for improving the reading skills of children in settings with a similar socio-economic status and achievement profile to ours. The review highlights a gap in research that should be addressed due to the potential positive impact ICT reading interventions could have in such contexts.

Speech and language therapy is an evidence-based profession so professionals recommending or facilitating ICT literacy interventions will need to know which interventions have been shown to be effective, and the extent of the evidence. Some of the interventions in this review have been researched in many studies including other countries in Africa. We described the 'big four' ICT interventions emerging from the review which were GraphoGame, ABRACADABRA, Reading RACES and Chassymo. They are starting to emerge as programmes that could be considered for at-scale intervention in South Africa. In particular GraphoGame and ABRACADABRA have been used in many different contexts, including majority world countries. GraphoGame has been successfully adapted into

TABLE 3: Information and communication technology studies carried out in the majority world - Summary of interventions in the scoping review.

\begin{tabular}{|c|c|c|c|c|c|}
\hline Study & Skills targeted in activities & $\begin{array}{l}\text { Mode of } \\
\text { delivery }\end{array}$ & Facilitator & Dosage & Outcomes \\
\hline \multicolumn{6}{|l|}{ ABRACADABRA } \\
\hline $\begin{array}{l}\text { Lysenko et al. } \\
\text { (2019) }\end{array}$ & $\begin{array}{l}\text { Phoneme-grapheme } \\
\text { knowledge and phonics, } \\
\text { phonemic awareness, word } \\
\text { reading, fluency, vocabulary, } \\
\text { listening and reading } \\
\text { comprehension and writing }\end{array}$ & Computer & $\begin{array}{l}\text { Trained } \\
\text { teachers }\end{array}$ & $\begin{array}{l}16 \text { weeks } \\
2 \mathrm{~h} \text { per week }\end{array}$ & $\begin{array}{l}\text { Statistically significant difference between } \\
\text { experimental and control groups (in favour of the } \\
\text { experimental group) on measures of word reading, } \\
\text { vocabulary, reading and listening comprehension. } \\
\text { Experimental participants significantly } \\
\text { outperformed control participants in examinations. }\end{array}$ \\
\hline $\begin{array}{l}\text { Abrami et al. } \\
\text { (2016) }\end{array}$ & $\begin{array}{l}\text { Phoneme-grapheme } \\
\text { knowledge and phonics, } \\
\text { phonemic awareness, word } \\
\text { reading, fluency, vocabulary, } \\
\text { listening and reading } \\
\text { comprehension and writing }\end{array}$ & Computer & $\begin{array}{l}\text { Trained } \\
\text { teachers }\end{array}$ & $\begin{array}{l}13 \text { weeks } \\
2 \mathrm{~h} \text { per week }\end{array}$ & $\begin{array}{l}\text { Intervention group made significant gains in reading } \\
\text { and listening comprehension compared to control } \\
\text { group. Medium effect sizes were found. } \\
\text { No significant difference between the groups on } \\
\text { other norm-referenced measures. Children in the } \\
\text { intervention group outperformed children in the } \\
\text { control group in their exams. }\end{array}$ \\
\hline \multicolumn{6}{|l|}{ GraphoGame } \\
\hline $\begin{array}{l}\text { Ngorosho (2018) } \\
\text { (Kiswahili } \\
\text { GraphoGame) }\end{array}$ & $\begin{array}{l}\text { Phoneme-grapheme } \\
\text { knowledge and phonics, } \\
\text { phonological awareness and } \\
\text { word reading }\end{array}$ & Cell phones & $\begin{array}{l}\text { Learners } \\
\text { independent }\end{array}$ & $\begin{array}{l}3 \text { sessions per day } \\
10 \text { min per session } \\
\text { Five days per week } \\
\text { Total intervention } 2-4 \mathrm{~h}\end{array}$ & $\begin{array}{l}\text { Significant improvement for both GraphoGame and } \\
\text { classroom instruction; GraphoGame had more } \\
\text { improvement than classroom instruction. }\end{array}$ \\
\hline $\begin{array}{l}\text { Patel et al. (2018) } \\
\text { (GraphoLearn) }\end{array}$ & $\begin{array}{l}\text { Phoneme-grapheme } \\
\text { knowledge and phonics, } \\
\text { phonological awareness and } \\
\text { word reading }\end{array}$ & Tablet & $\begin{array}{l}\text { Learners } \\
\text { independent }\end{array}$ & $\begin{array}{l}8 \text { weeks } \\
20-30 \text { min per session } \\
6 \text { sessions per week }\end{array}$ & $\begin{array}{l}\text { Significant differences in favour of the intervention } \\
\text { group for all GraphoLearn in-game measures. No } \\
\text { significant differences between the groups for } \\
\text { standardised measures. }\end{array}$ \\
\hline $\begin{array}{l}\text { Jere-Folotiya } \\
\text { et al. (2014) } \\
\text { (ciNyanja } \\
\text { GraphoGame) }\end{array}$ & $\begin{array}{l}\text { Phoneme-grapheme } \\
\text { knowledge and phonics }\end{array}$ & Cell phone & $\begin{array}{l}\text { Learners } \\
\text { independent }\end{array}$ & $\begin{array}{l}7-9 \text { min sessions } \\
6 \text { sessions per day } \\
3-5 \text { days containing sessions per week } \\
94 \text { min }(M) \text { total intervention }\end{array}$ & $\begin{array}{l}\text { The intervention improved the literacy skills of the } \\
\text { participants (intervention learners significantly } \\
\text { outperformed control learners). }\end{array}$ \\
\hline
\end{tabular}

Note: Please see the full reference list of this article, Dean, J., Pascoe, M. \& Le Roux, J., 2021, 'Information and communication technology reading interventions: A scoping review', Reading \& Writing 12(1), a294. https://doi.org/10.4102/rw.v12i1.294, for more information. 
many languages and this adaptation would be particularly important for its use in South Africa too. Here it would be important for the programme to be adapted into learners' home languages, as well as second or additional languages because in Grade 4 there is a shift from mother tongue instruction to English or Afrikaans instruction in schools. Care would need to be taken to ensure cultural and linguistic appropriateness, but the effective adaptation and use in Zambia and Tanzania suggests that adaptation would be feasible. Home language interventions could be used to scaffold and support the development of English or Afrikaans language and literacy skills. The review found only a few studies with bilingual participants, which does not reflect the high international rates of childhood bilingualism (Paradis, Genesee \& Crago 2011). There is also a great need for interventions to be developed specifically for bilingual learners and for their efficacy to be determined.

Although the potential of interventions such as GraphoGame for South Africa is clear, it is not to say that this intervention works better than other interventions. Rather it has been researched more and the process of evidence generation is more advanced than for some other programmes. The relative cost effectiveness and efficiency (ease of implementation) of each approach would need to be examined further so that the approaches with the strongest evidence and feasibility for implementation are selected at schools. Evidence-based practice refers to interventions and their application in particular contexts with particular individuals. Thus, interventions that are designed and tested in a particular setting with a group of children with particular characteristics may not be appropriate or effective for another setting or group of children. The use of established interventions would also not preclude the urgent need to develop and trial our own local interventions that may ultimately prove to be as effective.

South Africa has one of the highest mobile phone penetrations in the world (Ojo 2018) and therefore the use of smartphonebased interventions for improving both health and education is relevant. The two GraphoGame studies undertaken in Africa involved children using smartphones to access the intervention, and this approach may be worth considering further. During the COVID-19 pandemic when South Africa's schools were closed many children had no access to learning materials or any sort of educational support.

Smartphone-based apps such as GraphoGame could enable children to develop their reading skills anywhere and anytime, especially if the relevant apps were freely available and access to the data was zero-rated. Although findings related to intervention intensity and facilitation did not reveal clear patterns related to their relative effectiveness, studies with four to five sessions per week produced more widespread improvements than those with one to three sessions per week.

The studies conducted in the majority world reported a number of challenges associated with intervention delivery. Information and communication technology-based reading intervention studies conducted in similar contexts should provide training to learners on how to use technological devices and provide opportunities for learners to become familiar with the devices before intervention commences. Smartphones are likely to be familiar to many children, but they may not be able to have access to their own device and may not be able to bring it to school. Innovative solutions to venue constraints such as having multiple intervention slots where only a few learners attend an intervention at each time, rearranging furniture and using classroom dividers, and dividing learners into groups may need to be considered in schools - highlighting a need for addressing basic infrastructure, which remains problematic in many South African schools. There is an urgent need to develop culturally and linguistically appropriate reading, teaching and assessment materials together with training opportunities related to how resources can be used. Workshops for teachers that focus on effective literacy instruction, and for parents who have low literacy levels related to how they can support their children's literacy learning, will also be valuable and should be seen as part of a broader solution to addressing challenges that an ICT intervention alone will not be able to address.

The scoping review may present a biased impression of the effectiveness of ICT interventions as studies demonstrating no effect are less likely to be published (Djulbegovic \& Guyatt 2017). Our review was also limited in that we only focused on a 10-year period and did not consider studies that were published in languages other than English and that used non-experimental methods. A systematic review or metaanalysis that seeks to address more specific questions about ICT reading interventions would be helpful, along with further studies that trial and evaluate ICT interventions in the majority world where they are most needed.

\section{Conclusion}

The scoping review described the characteristics of 49 ICT-based reading intervention studies for primary school children, published in the past decade. Findings indicate a promising range of different ICT-based interventions, most of which demonstrate positive outcomes although wideranging outcomes measures and research designs have been used. Only a small proportion of the studies were undertaken in the majority world. There is a great need for further work in this context and in particular in South Africa where reading outcomes are poor. It is clear that ICT-based approaches to reading intervention can lead to improvements in learners' reading skills, but further research is needed to determine if any of these interventions could be relevant for South African learners or to guide the development of innovative ICTbased interventions responsive to the needs of South African children and educators.

\section{Acknowledgements Competing interests}

The authors declare that they have no financial or personal relationships that may have inappropriately influenced them in writing this article. 


\section{Authors' contributions}

J.D., M.P. and J.1.R. contributed to the design and implementation of the research, to the analysis of the results and to the writing of the article.

\section{Ethical considerations}

This article followed all ethical standards for carrying out research.

\section{Funding information}

This research received no specific grant from any funding agency in the public, commercial or not-for-profit sectors.

\section{Data availability}

The authors confirm that the data supporting the findings of this study are available within the article.

\section{Disclaimer}

The views and opinions expressed in this article are those of the authors and do not necessarily reflect the official policy or position of any affiliated agency of the authors.

\section{References}

Abrami, P.C., Wade, C.A., Lysenko, L., Marsh, J. \& Gioko, A., 2016, 'Using educational technology to develop early literacy skills in sub-Saharan Africa', Education and Information Technologies 21(4), 945-964. https://doi.org/10.1007/s10639-0149362-4

Arksey, H. \& O'Malley, L., 2005, 'Scoping studies: Towards a methodological framework', International Journal of Social Research Methodology 8(1), 19-32. https://doi.org/10.1080/1364557032000119616

Baker, D.L., Basaraba, D.L., Smolkowski, K., Conry, J., Hautala, J., Richardson, U. et al., 2017, 'Exploring the cross-linguistic transfer of reading skills in Spanish to English in the context of a computer adaptive reading intervention', Bilingual Research Journal 40(2), 222-239. https://doi.org/10.1080/15235882.2017. 1309719

Barber, M., Cartledge, G., Council III, M., Konrad, M., Gardner, R. \& Telesman, A.O., 2018, 'The effects of computer-assisted culturally relevant repeated readings on English learners' fluency and com
A Contemporary Journal 16(2), 205-229.

Bennett, J.G., Gardner, R.I., Cartledge, G., Ramnath, R. \& Council, M.I., 2017, 'Secondgrade urban learners: Preliminary findings for a computer-assisted, culturally relevant, repeated reading intervention', Education and Treatment of Children relevant, repeated reading intervention', Education and
40(2), 145-186. https://doi.org/10.1353/etc.2017.0008

Campuzano, L., Dynarski, M., Agodini, R. \& Rall, K., 2009, Effectiveness of reading and mathematics software products: Findings from two student cohorts, Institute of Education Sciences, Washington, DC.

Chambers, B., Slavin, R.E., Madden, N.A., Abrami, P., Logan, M.K. \& Gifford, R., 2011 'Small-group, computer-assisted tutoring to improve reading outcomes for struggling first and second graders', The Elementary School Journal 111(4), 625-640. https://doi.org/10.1086/659035

Cheung, A.C. \& Slavin, R.E., 2011, The effectiveness of education technology for enhancing reading achievement: A meta-analysis, pp. 1-48, Center for Research and Reform in Education, Baltimore, MD.

Cheung, A.C. \& Slavin, R.E., 2013, 'Effects of educational technology applications on reading outcomes for struggling readers: A best evidence synthesis', Reading Research Quarterly 48(3), 277-299. https://doi.org/10.1002/rrq.50

Council III, M.R., Gardner III, R., Cartledge, G. \& Telesman, A.O., 2019, 'Improving reading within an urban elementary school: Computerized intervention and paraprofessional factors', Preventing School Failure: Alternative Education for Children and Youth 63(2), 162-174. https://doi.org/10.1080/1045988X.2018. 1540392

Cullen, J., Keesey, S. \& Alber-Morgan, S.R., 2013, 'The effects of computer-assisted instruction using Kurzweil 3000 on sight word acquisition for students with mild disabilities', Education and Treatment of Children 36(2), 87-103. https://doi. org/10.1353/etc.2013.0017

Department of Basic Education, 2014, Report on the Annual National Assessments 2014, Government Printing Works, Pretoria.

Djulbegovic, B. \& Guyatt, G.H., 2017, 'Progress in evidence-based medicine: A quarter century on', The Lancet 390(10092), 415-423. https://doi.org/10.1016/S0140 6736(16)31592-6
Ecalle, J., Kleinsz, N. \& Magnan, A., 2013, 'Computer-assisted learning in young poor readers: The effect of grapho-syllabic training on the development of word reading and reading comprehension', Computers in Human Behavior 29(4), 1368-1376. https://doi.org/10.1016/j.chb.2013.01.041

Ecalle, J., Magnan, A. \& Calmus, C., 2009, 'Lasting effects on literacy skills with a computer-assisted learning using syllabic units in low-progress readers', Computers \& Education 52(3), 554-561. https://doi.org/10.1016/j.compedu.2008.10.010

El Zein, F., Gevarter, C., Bryant, B., Son, S.H., Bryant, D., Kim, M. et al., 2016, 'A comparison between iPad-assisted and teacher-directed reading instruction for students with autism spectrum disorder (ASD)', Journal of Developmental and Physical Disabilities 28(2), 195-215. https://doi.org/10.1007/s10882-015-9458-9

Fälth, L., Gustafson, S., Tjus, T., Heimann, M. \& Svensson, I., 2013, 'Computer-assisted interventions targeting reading skills of children with reading disabilities: A longitudinal study', Dyslexia 19(1), 37-53. https://doi.org/10.1002/dys.1450

Galuschka, K., Ise, E., Krick, K. \& Schulte-Körne, G., 2014, 'Effectiveness of treatment approaches for children and adolescents with reading disabilities: A meta-analysis of randomized controlled trials', PLoS One 9(2), 1-12. https://doi.org/10.1371/ journal.pone.0089900

Gibson, L. \& Musti-Rao, S., 2017, 'Computer-based strategies to improve reading skills', in L. Gibson \& F. Obiakor (eds.), Computer-based technology for special and multicultural education: Enhancing 21st century learning, pp. 59-72, Plural Publishing, San Diego.

Gustafson, S., Fälth, L., Svensson, I., Tjus, T. \& Heimann, M., 2011, 'Effects of three interventions on the reading skills of children with reading disabilities in grade 2 ', Journal of Learning Disabilities 44(2), 123-135. https://doi.org/10.1177/00222 Journal of Learn

Heikkilä, R., Aro, M., Närhi, V., Westerholm, J. \& Ahonen, T., 2013, 'Does training in syllable recognition improve reading speed? A computer-based trial with poor readers from second and third grade', Scientific Studies of Reading 17(6), 398414. https://doi.org/10.1080/10888438.2012.753452

Horne, J.K., 2017, 'Reading comprehension: A computerized intervention with primaryage poor readers', Dyslexia 23(2), 119-140. https://doi.org/10.1002/dys.1552

Howie, S., Combrinck, C., Roux, K., Tshele, M., Mokoena, G. \& Palane, N.M., 2017, PIRLS 2016, Centre for Evaluation and Assessment, Pretoria.

Jamshidifarsani, H., Garbaya, S., Lim, T., Blazevic, P. \& Ritchie, J.M., 2019, 'Technologybased reading intervention programs for elementary grades: An analytical review', Computers \& Education 128, 427-451. https://doi.org/10.1016/j.compedu.2018. 10.003

Jere-Folotiya, J., Chansa-Kabali, T., Munachaka, J.C., Sampa, F., Yalukanda, C. Westerholm, J. et al., 2014, 'The effect of using a mobile literacy game to improve literacy levels of grade one students in Zambian schools', Educational Technology literacy levels of grade one students in Zambian schools', Educational Technology
Research and Development 62 (4), 417-436. https://doi.org/10.1007/s11423-014Research
9342-9

Kamykowska, J., Haman, E., Richardson, U., Latvala, J.M. \& Lyytinen, H., 2014 'Developmental changes of early reading skills in six-year-old Polish children and GraphoGame as a computer-based intervention to support them', L1 Educational GraphoGame as a computer-based intervention
Studies in Language and Literature 13, 1-17.

Kim, J.S., Capotosto, L., Hartry, A. \& Fitzgerald, R., 2011, 'Can a mixed-method literacy intervention improve the reading achievement of low-performing elementary school students in an after-school program? Results from a randomized controlled trial of READ 180 enterprise', Educational Evaluation and Policy Analysis 33(2), 183-201. https://doi.org/10.3102/0162373711399148

Kim, J.S., Samson, J.F., Fitzgerald, R. \& Hartry, A., 2010, 'A randomised experiment of a mixed-methods literacy intervention for struggling readers in grades 4-6: Effects on word reading efficiency, reading comprehension and vocabulary, and oral reading fluency', Reading and Writing 23(9), 1109-1129. https://doi.org/10.1007/ s11145-009-9198-2

Kleinsz, N., Potocki, A., Ecalle, J. \& Magnan, A., 2017, 'Profiles of French poor readers: Underlying difficulties and effects of computerized training programs', Learning and Individual Differences 57, 45-57. https://doi.org/10.1016/j.lindif.2017.05.009

Kyle, F., Kujala, J., Richardson, U., Lyytinen, H. \& Goswami, U., 2013, 'Assessing the effectiveness of two theoretically motivated computer-assisted reading interventions in the United Kingdom: GG Rime and GG Phoneme', Reading Research Quarterly 48(1), 61-76. https://doi.org/10.1002/rrq.038

Larabee, K.M., Burns, M.K. \& McComas, J.J., 2014, 'Effects of an iPad-supported phonics intervention on decoding performance and time on-task', Journal of Behavioral Education 23(4), 449-469. https://doi.org/10.1007/s10864-014-9214-8

Lindeblad, E., Nilsson, S., Gustafson, S. \& Svensson, I., 2016, 'Assistive technology as reading interventions for children with reading impairments with a one-year follow-up', Disability and Rehabilitation: Assistive Technology 12(7), 713-724. follow-up', Disability and Rehabilitation: Assistive
https://doi.org/10.1080/17483107.2016.1253116

Lysenko, L.V. \& Abrami, P.C., 2014, 'Promoting reading comprehension with the use of technology', Computers \& Education 75, 162-172.

Lysenko, L., Abrami, P.C., Wade, C.A., Marsh, J.P., WaGioko, M. \& Kiforo, E., 2019, 'Promoting young Kenyans' growth in literacy with educational technology: A tale of two years of implementation', International Journal of Educational Research 95, 176-189. https://doi.org/10.1016/j.compedu.2014.01.010

Macaruso, P. \& Rodman, A., 2009, 'Benefits of computer-assisted instruction for struggling readers in middle school', European Journal of Special Needs Education 24(1), 103-113. https://doi.org/10.1080/08856250802596774

Madden, N. \& Slavin, R., 2017, 'Evaluations of technology-assisted small-group tutoring for struggling readers', Reading \& Writing Quarterly 33(4), 327-334. https://doi.org/10.1080/10573569.2016.1255577

Mak, B.S., Cheung, A.C., Guo, X., Abrami, P.C. \& Wade, A., 2017, 'Examining the impact of the ABRACADABRA (ABRA) web-based literacy program on primary schoo students in Hong Kong', Education and Information Technologies 22(6), 2671-2691. https://doi.org/10.1007/s10639-017-9620-3 
McTigue, E.M. \& Uppstad, P.H., 2018, 'Getting serious about serious games: Best practices for computer games in reading classrooms', The Reading Teacher 72(4), practices for computer games in reading class

Messer, D. \& Nash, G., 2018, 'An evaluation of the effectiveness of a computer-assisted reading intervention', Journal of Research in Reading 41(1), 140-158. https://doi. org/10.1111/1467-9817.12107

Mize, M., Bryant, D.P. \& Bryant, B.R., 2019, 'Teaching reading to students with learning disabilities: Effects of combined iPad-assisted and peer-assisted instruction on oral reading fluency performance', Assistive Technology 32(6), 1-8. https://doi.or g/10.1080/10400435.2018.1559896

Moran, J., Ferdig, R.E., Pearson, P.D., Wardrop, J. \& Blomeyer Jr, R.L., 2008, 'Technology and reading performance in the middle-school grades: A meta-analysis with recommendations for policy and practice', Journal of Literacy Research 40(1) 6-58. https://doi.org/10.1080/10862960802070483

Moser, G.P., Morrison, T.G. \& Wilcox, B., 2017, 'Supporting fourth-grade students' word identification using application software', Reading Psychology 38(4), 349-368. https://doi.org/10.1080/02702711.2016.1278414

Mullis, I., Martin, M., Foy, P. \& Hooper, M., 2017, PIRLS 2016 international results in reading, International Association for the Evaluation of Educational Achievement, Chestnut Hill, MA.

Musti-Rao, S., Lo, Y.Y. \& Plati, E., 2015, 'Using an $\mathrm{iPad}^{\circledR}$ app to improve sight word reading fluency for at-risk first graders', Remedial and Special Education 36(3), 154-166. https://doi.org/10.1177/0741932514541485

Nadler-Nir, E. \& Pascoe, M., 2016, 'Language-based literacy interventions', in G. Reid \& L. Peer (eds.), Multilingualism, literacy and dyslexia, pp. 89-103, Routledge, Abingdon.

National Reading Panel, 2000, Teaching children to read: An evidence-based assessment of the scientific research literature on reading and its implications for reading instruction, National Institute of Child Health and Human Development, Washington, DC.

Ngorosho, D., 2018, 'Enhancing the acquisition of basic reading skills in Kiswahili using GraphoGame', Papers in Education and Development 35, 1-26.

O’Brien, B.A., Begum, M. \& Onnis, L., 2019, 'Technology-based tools for English literacy intervention: Examining intervention grain size and individual differences', Frontiers in Psychology 10, 1-21. https://doi.org/10.3389/fpsyg.2019.02625

Ojanen, E., Ronimus, M., Ahonen, T., Chansa-Kabali, T., February, P., Jere-Folotiya, J. et al., 2015, 'GraphoGame - A catalyst for multi-level promotion of literacy in diverse contexts', Frontiers in Psychology 6, 671. https://doi.org/10.3389/fpsyg 2015.00671

Ojo, A.I., 2018, 'mHealth interventions in South Africa: A review', SAGE Open 8(1), 2158244018767223. https://doi.org/10.1177/2158244018767223

Ozbek, A.B. \& Girli, A., 2017, 'The effectiveness of a tablet computer-aided intervention program for improving reading fluency' Universal Journal of Educational Research 5(5), 757-764. https://doi.org/10.13189/ujer.2017.050508

Paradis, J., Genesee, F. \& Crago, M.B., 2011, Dual language development and disorders: A handbook on bilingualism and second language learning, $2^{\text {nd }}$ edn. Paul H. Brookes Publishing Co, Baltimore, MD.

Patel, P., Torppa, M., Aro, M., Richardson, U. \& Lyytinen, H., 2018, 'GraphoLearn India: The effectiveness of a computer-assisted reading intervention in supporting struggling readers of English', Frontiers in Psychology 9, 1-14. https://doi. org/10.3389/fpsyg.2018.01045

Ponce, H.R., López, M.J. \& Mayer, R.E., 2012, 'Instructional effectiveness of a computer-supported program for teaching reading comprehension strategies', Computers \& Education 59(4), 1170-1183. https://doi.org/10.1016/j.compedu. 2012.05.013
Potocki, A., Ecalle, J. \& Magnan, A., 2013, 'Effects of computer-assisted comprehension training in less skilled comprehenders in second grade: A one-year follow-up study', Computers \& Education 63, 131-140. https://doi.org/10.1016/j.compedu. study', Computer
2012.12.011

Rivera, C.J., Mason, L., Moser, J. \& Ahlgrim-Delzell, L., 2014, 'The effects of an iPad ${ }^{\circledR}$ multimedia shared story intervention on vocabulary acquisition for an English language learner', Journal of Special Education Technology 29(4), 31-48. https:// doi.org/10.1177/016264341402900403

Saine, N.L., Lerkkanen, M.K., Ahonen, T., Tolvanen, A. \& Lyytinen, H., 2011, 'Computerassisted remedial reading intervention for school beginners at risk for reading disability', Child Development 82(3), 1013-1028. https://doi.org/10.1111/j.14678624.2011.01580.x

Savage, R.S., Abrami, P., Hipps, G. \& Deault, L., 2009, 'A randomized controlled trial study of the ABRACADABRA reading intervention program in grade 1 ', Journal of Educational Psychology 101(3), 590. https://doi.org/10.1037/a0014700

Savage, R.S., Erten, O., Abrami, P., Hipps, G., Comaskey, E. \& Van Lierop, D., 2010 'ABRACADABRA in the hands of teachers: The effectiveness of a web-based literacy intervention in grade 1 language arts programs', Computers \& Education 55(2), 911-922. https://doi.org/10.1016/j.compedu.2010.04.002

Schneider, D., Chambers, A., Mather, N., Bauschatz, R., Bauer, M. \& Doan, L., 2016, 'The effects of an ICT-based reading intervention on students' achievement in grade two', Reading Psychology 37(5), 793-831. https://doi.org/10.1080/027027 11.2015.1111963

Shannon, L.C., Styers, M.K., Wilkerson, S.B. \& Peery, E., 2015, 'Computer-assisted learning in elementary reading: A randomized control trial', Computers in the Schools 32(1), 20-34. https://doi.org/10.1080/07380569.2014.969159

Solheim, O.J., Frijters, J.C., Lundetræ, K. \& Uppstad, P.H., 2018, 'Effectiveness of an early reading intervention in a semi-transparent orthography: A group randomised controlled trial', Learning and Instruction 58, 65-79. https://doi.org/10.1016/j. learninstruc.2018.05.004

Spaull, N., 2013, 'Poverty \& privilege: Primary school inequality in South Africa', International Journal of Educational Development 33(5), 436-447. https://doi. International Journal of Educational
org/10.1016/j.ijedudev.2012.09.009

Suggate, S.P., 2016, 'A meta-analysis of the long-term effects of phonemic awareness, phonics, fluency, and reading comprehension interventions', Journal of Learning Disabilities 49(1), 77-96. https://doi.org/10.1177/002221 9414528540

Torgesen, J.K., Wagner, R.K., Rashotte, C.A., Herron, J. \& Lindamood, P., 2010, 'Computer-assisted instruction to prevent early reading difficulties in students at risk for dyslexia: Outcomes from two instructional approaches', Annals of Dyslexia 60(1), 40-56. https://doi.org/10.1007/s11881-009-0032-y

Tyler, E.J., Hughes, J.C., Beverley, M. \& Hastings, R.P., 2015, 'Improving early reading skills for beginning readers using an online programme as supplementary instruction', European Journal of Psychology of Education 30(3), 281-294. https:// doi.org/10.1007/s10212-014-0240-7

Van de Ven, M., De Leeuw, L., Van Weerdenburg, M. \& Steenbeek-Planting, E.G., 2017 'Early reading intervention by means of a multicomponent reading game', Journa of Computer Assisted Learning 33(4), 320-333. https://doi.org/10.1111/jcal.12181

Walcott, C.M., Marett, K. \& Hessel, A.B., 2014, 'Effectiveness of a computer-assisted intervention for young children with attention and reading problems', Journal of Applied School Psychology 30(2), 83-106. https://doi.org/10.1080/15377903.2013. 874389

Yaw, J.S., Skinner, C.H., Parkhurst, J., Taylor, C.M., Booher, J. \& Chambers, K., 2011, 'Extending research on a computer-based sight-word reading intervention to a student with autism', Journal of Behavioral Education 20(1), 44-54. https://doi org/10.1007/s10864-010-9118-1 


\section{Appendix 1}

TABLE 1-A1: Design and participant characteristics of studies included in the information and communication technology-based reading intervention scoping review.

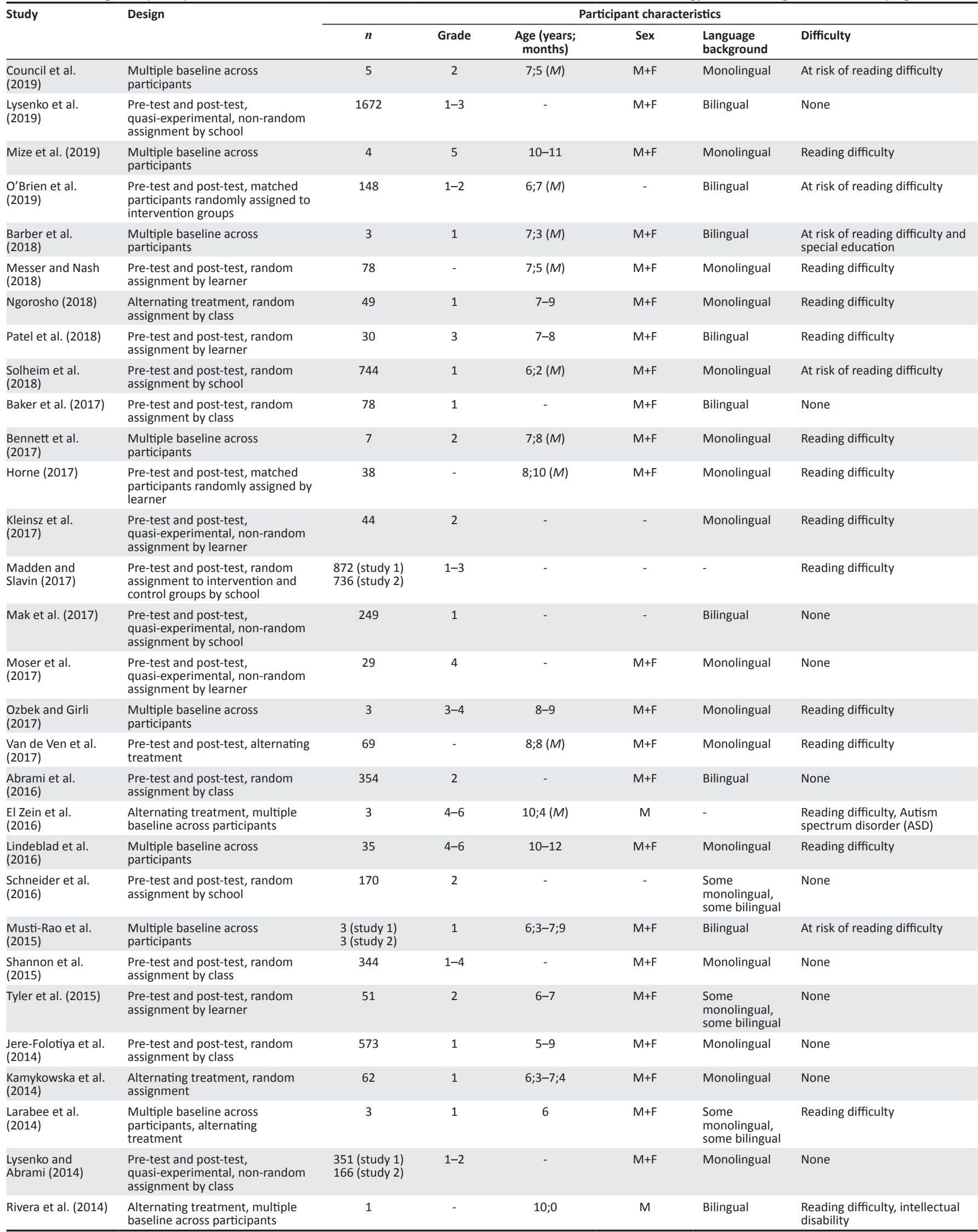


TABLE 1-A1 (Continues...): Design and participant characteristics of studies included in the information and communication technology-based reading intervention scoping review.

\begin{tabular}{|c|c|c|c|c|c|c|c|}
\hline \multirow[t]{2}{*}{ Study } & \multirow[t]{2}{*}{ Design } & \multicolumn{6}{|c|}{ Participant characteristics } \\
\hline & & $n$ & Grade & $\begin{array}{l}\text { Age (years; } \\
\text { months) }\end{array}$ & Sex & $\begin{array}{l}\text { Language } \\
\text { background }\end{array}$ & Difficulty \\
\hline $\begin{array}{l}\text { Walcott, Marett } \\
\text { and Hessel (2014) }\end{array}$ & $\begin{array}{l}\text { Multiple baseline across } \\
\text { participants }\end{array}$ & $\begin{array}{l}3 \text { (study } 1 \text { ) } \\
3 \text { (study 2) }\end{array}$ & $\begin{array}{l}1 \text { (study } 1 \text { ) } \\
2 \text { (study } 2 \text { ) }\end{array}$ & $\begin{array}{l}6-7 \text { (study } 1) \\
8-9 \text { (study } 2)\end{array}$ & $\begin{array}{l}M+F(\text { study } 1) \\
M(\text { study } 2)\end{array}$ & Monolingual & Reading difficulty \\
\hline $\begin{array}{l}\text { Cullen, Keesey and } \\
\text { Alber-Morgan } \\
\text { (2013) }\end{array}$ & $\begin{array}{l}\text { Multiple baseline across } \\
\text { participants }\end{array}$ & 4 & 4 & - & $M+F$ & Monolingual & $\begin{array}{l}\text { Reading difficulty (additional } \\
\text { difficulties: } 2 \text { with learning } \\
\text { disabilities, } 1 \text { with intellectual } \\
\text { disability and } 1 \text { with attention } \\
\text { deficit and hyperactivity } \\
\text { disorder). }\end{array}$ \\
\hline Ecalle et al. (2013) & $\begin{array}{l}\text { Pre-test and post-test, random } \\
\text { assignment by learner }\end{array}$ & $\begin{array}{l}27 \text { (study } 1) \\
18 \text { (study } 2)\end{array}$ & $\begin{array}{l}2 \text { (study } 1 \text { ) } \\
1 \text { (study 2) }\end{array}$ & $\begin{array}{l}7 ; 6 M \text { (study } 1) \\
6 ; 6 M \text { (study 2) }\end{array}$ & $\mathrm{M}+\mathrm{F}$ & Monolingual & Reading difficulty \\
\hline Fälth et al. (2013) & $\begin{array}{l}\text { Pre-test and post-test, random } \\
\text { assignment by learner }\end{array}$ & 130 & 2 & - & $\mathrm{M}+\mathrm{F}$ & Monolingual & Reading difficulty \\
\hline $\begin{array}{l}\text { Heikkilä et al. } \\
\text { (2013) }\end{array}$ & $\begin{array}{l}\text { Pre-test and post-test, random } \\
\text { assignment by learner }\end{array}$ & 150 & $2-3$ & $9 ; 2$ & $M+F$ & Monolingual & Reading difficulty \\
\hline Kyle et al. (2013) & $\begin{array}{l}\text { Pre-test and post-test, matched } \\
\text { subject, random assignment of } \\
\text { matched groups }\end{array}$ & 31 & 2 & 6 & $\mathrm{M}+\mathrm{F}$ & Monolingual & Reading difficulty \\
\hline $\begin{array}{l}\text { Potocki et al. } \\
\text { (2013) }\end{array}$ & $\begin{array}{l}\text { Pre-test and post-test, random } \\
\text { assignment by learner }\end{array}$ & 30 & 2 & $7 ; 6-7 ; 7(M)$ & - & Monolingual & Language difficulty \\
\hline Ponce et al. (2012) & $\begin{array}{l}\text { Pre-test and post-test, } \\
\text { quasi-experimental, non-random } \\
\text { assignment by school }\end{array}$ & 1041 & 4 & - & $M+F$ & - & None \\
\hline $\begin{array}{l}\text { Chambers et al. } \\
\text { (2011) }\end{array}$ & $\begin{array}{l}\text { Pre-test and post-test, random } \\
\text { assignment by school }\end{array}$ & (33 schools) & $1-2$ & - & $\mathrm{M}+\mathrm{F}$ & - & Reading difficulty \\
\hline $\begin{array}{l}\text { Gustafson et al. } \\
\text { (2011) }\end{array}$ & $\begin{array}{l}\text { Pre-test and post-test, random } \\
\text { assignment by learner }\end{array}$ & 130 & 2 & - & $\mathrm{M}+\mathrm{F}$ & Monolingual & Reading disability \\
\hline Kim et al. (2011) & $\begin{array}{l}\text { Pre-test and post-test, random } \\
\text { assignment by learner }\end{array}$ & 312 & $4-6$ & $10 ; 5(M)$ & $M+F$ & - & Language difficulty \\
\hline Saine et al. (2011) & $\begin{array}{l}\text { Pre-test and post-test, random } \\
\text { assignment by learner }\end{array}$ & 166 & 1 & 7 & $\mathrm{M}+\mathrm{F}$ & Monolingual & At risk of reading difficulty \\
\hline Yaw et al. (2011) & $\begin{array}{l}\text { Multiple baselines across } \\
\text { participant }\end{array}$ & 1 & 6 & 12 & M & Monolingual & Reading difficulty, ASD \\
\hline Kim et al. (2010) & $\begin{array}{l}\text { Pre-test and post-test, random } \\
\text { assignment by learner }\end{array}$ & 294 & $4-6$ & - & $\mathrm{M}+\mathrm{F}$ & - & Language difficulty \\
\hline $\begin{array}{l}\text { Savage et al. } \\
\text { (2010) }\end{array}$ & $\begin{array}{l}\text { Pre-test and post-test, } \\
\text { quasi-experimental, non-random } \\
\text { assignment by class }\end{array}$ & 60 & 1 & $\begin{array}{l}6 ; 5-7 ; 1 \\
6 ; 5(M)\end{array}$ & $\mathrm{M}+\mathrm{F}$ & Monolingual & None \\
\hline $\begin{array}{l}\text { Torgesen et al. } \\
(2010)\end{array}$ & $\begin{array}{l}\text { Pre-test and post-test, random } \\
\text { assignment by learner }\end{array}$ & 112 & 1 & $6 ; 6(M)$ & $M+F$ & Monolingual & At risk of reading difficulty \\
\hline $\begin{array}{l}\text { Ecalle, Magnan } \\
\text { and Calmus (2009) }\end{array}$ & $\begin{array}{l}\text { Pre-test and post-test, random } \\
\text { assignment by learner }\end{array}$ & 28 & 1 & $6 ; 10(M)$ & $M+F$ & Monolingual & Reading difficulty \\
\hline $\begin{array}{l}\text { Macaruso and } \\
\text { Rodman (2009) }\end{array}$ & $\begin{array}{l}\text { Pre-test and post-test, random } \\
\text { assignment by class }\end{array}$ & 47 & $6-7$ & - & $M+F$ & - & Reading difficulty \\
\hline $\begin{array}{l}\text { Savage et al. } \\
\text { (2009) }\end{array}$ & $\begin{array}{l}\text { Pre-test and post-test, random } \\
\text { assignment by class }\end{array}$ & 144 & 1 & $6 ; 8(M)$ & $M+F$ & $\begin{array}{l}\text { Some } \\
\text { monolingual, } \\
\text { some bilingual }\end{array}$ & None \\
\hline
\end{tabular}

Note: Papers are ordered chronologically by year and alphabetically within years. Please see the full reference list of this article, Dean, J., Pascoe, M. \& Le Roux, J., 2021, 'Information and communication technology reading interventions: A scoping review', Reading \& Writing 12(1), a294. https://doi.org/10.4102/rw.v12i1.294, for more information.

$n$, sample size; M, mean; M, male; $F$, female; + indicates 'and'; -, information could not be found in the article. 


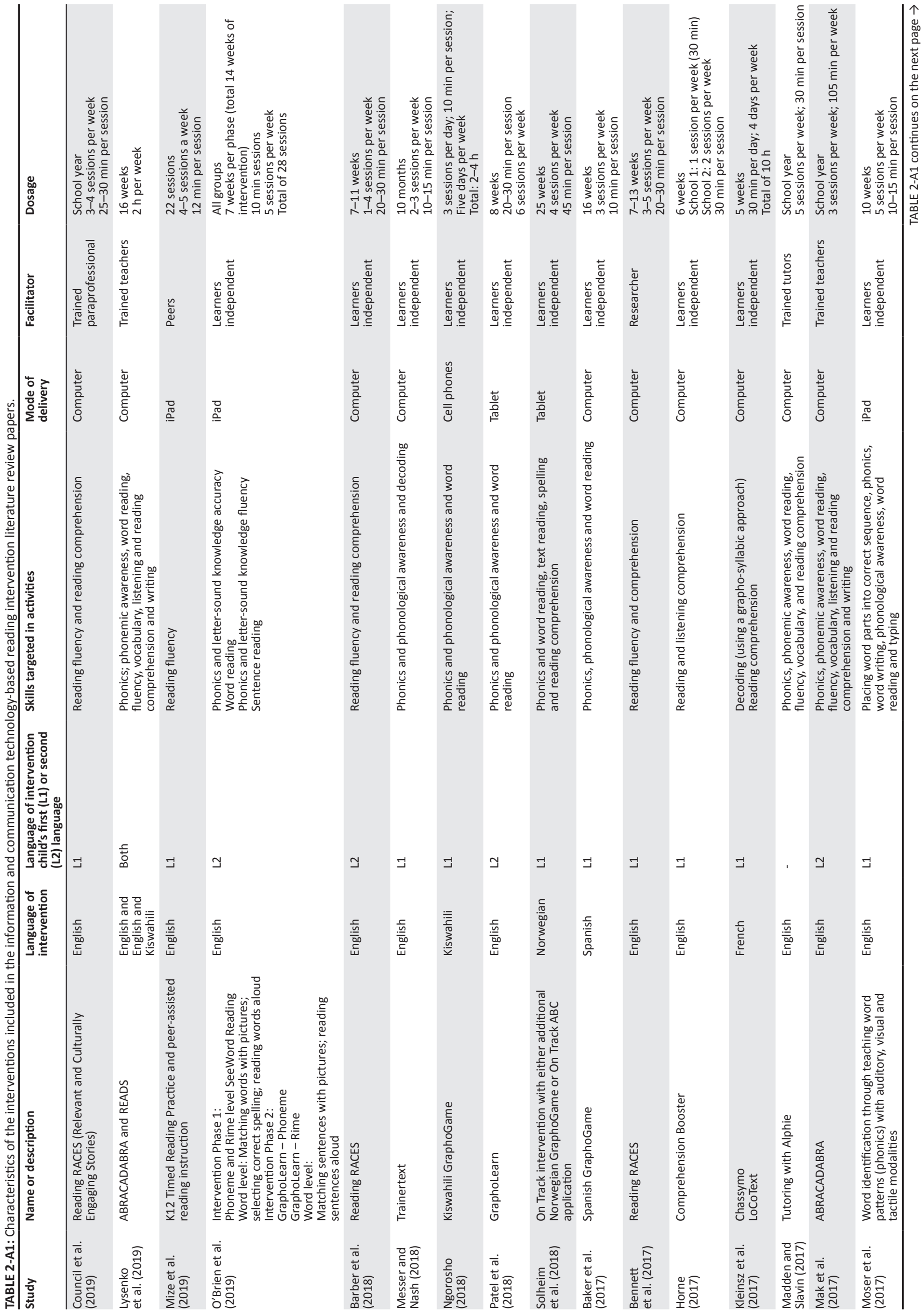




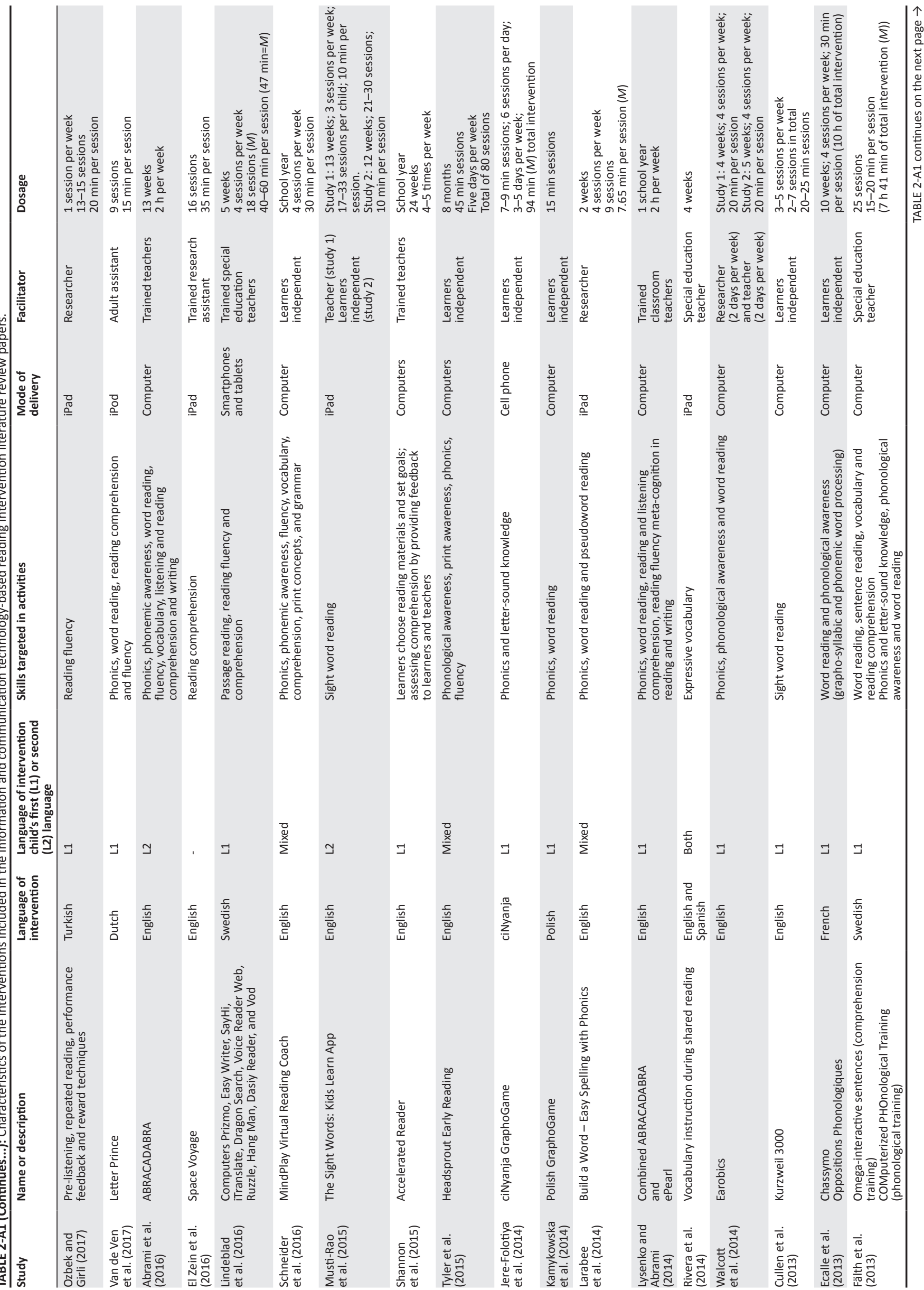




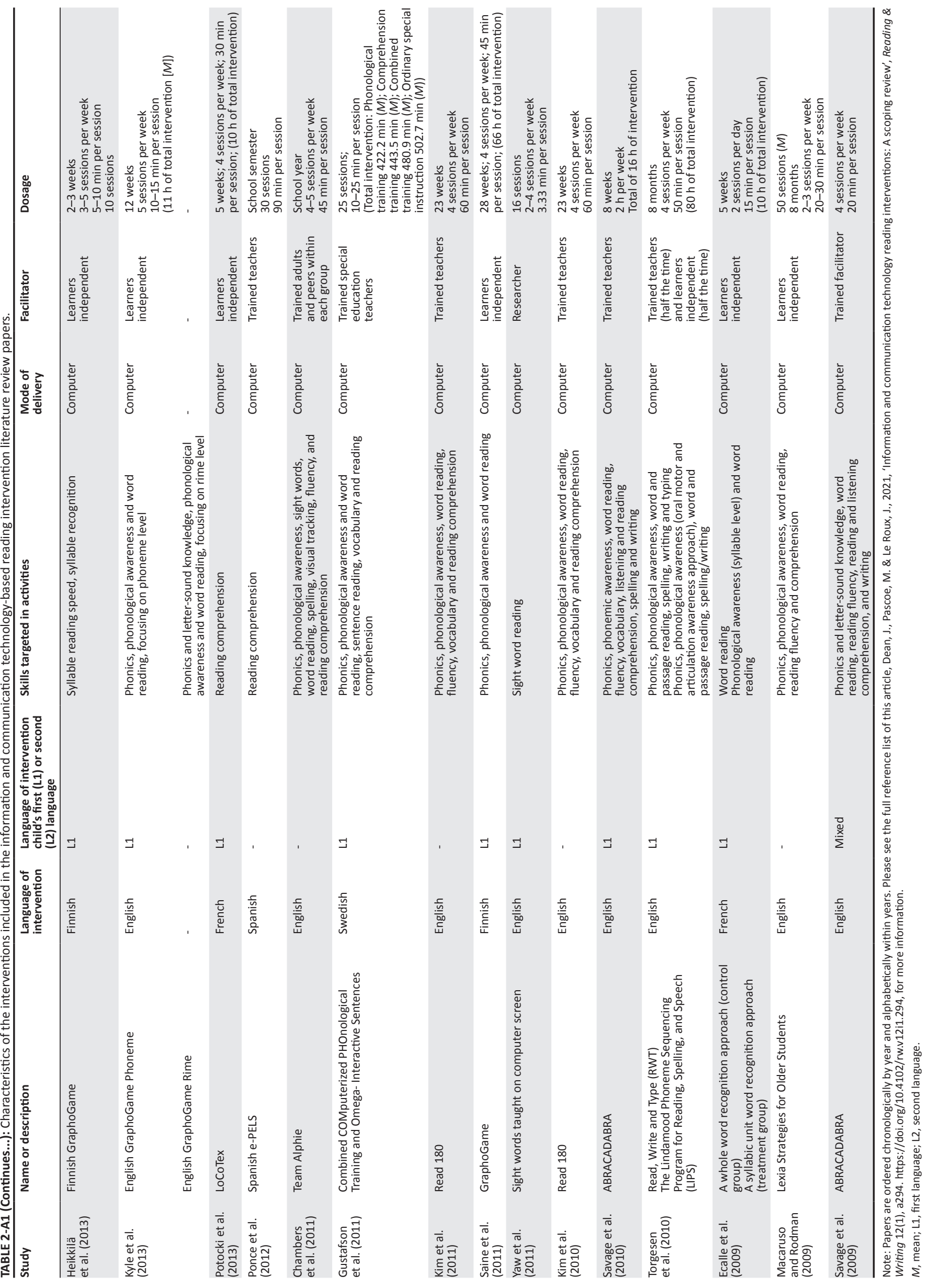


TABLE 3-A1: Outcome measures and results of the studies included in the information and communication technology-based reading intervention literature review.

\section{Study}

Council et al.

(2019)

Lysenko et al.

(2019)

Mize et al.

(2019)

O'Brien et al. Standardised measures of reading and decoding accuracy, reading (2019)

Informal measures of reading fluency and comprehension.

Standardised measures of word reading, word meaning (vocabulary), reading comprehension, listening comprehension and national examination results in English and the following subjects taught in English: Social Studies, Mathematics and Science. Informal measures of word reading accuracy and fluency. and decoding fluency, and spelling of words.

Barber et al. Informal measures of reading fluency and comprehension

(2018)

Messer and

Nash (2018)

Ngorosho

(2018)

Patel et al.

(2018)

Standardised measures of phonological awareness, phonological short-term memory, executive loaded working memory, naming speed, decoding and spelling.

Informal lexical decision tasks for letters, syllables and words and informal single word spelling test. Informal measures of letter knowledge and word reading. Standardised measures of word reading, sight word reading efficiency, pseudoword reading efficiency and spelling.

Solheim et al. Standardised measures of word reading, sentence reading and (2018) spelling.

Baker et al. Standardised measures of Spanish pseudoword and word reading (2017) standardised measures of English pseudoword reading and English reading accuracy and fluency.

Bennett et al. Non-standardised measures of reading fluency and comprehension.

(2017)

Horne (2017) Standardised test of reading comprehension, reading rate and reading accuracy.

Kleinsz et al. Standardised assessments of word reading, decoding, phonological (2017) skills, decoding fluency, receptive vocabulary and non-verbal reasoning. Informal measures of listening comprehension, reading comprehension, comprehension monitoring, and working memory.

Madden and Standardised assessments of word reading, fluency and

Slavin (2017) comprehension.

Mak et al. Standardised measures of word reading, vocabulary reading,

(2017) listening comprehension, phoneme segmentation fluency, and phoneme blending fluency.

Moser et al. Standardised measures of vocabulary, reading comprehension,

(2017) rate, accuracy, and spelling.

Ozbek and Informal measures of reading fluency.

Girli (2017)

Van de Ven

et al. (2017)

Abrami et al.

(2016)

Standardised tests of pseudoword reading, word and text reading, receptive vocabulary.

Norm-referenced tests of reading, reading vocabulary, reading comprehension, listening comprehension and end-of-year examination results in English and other subjects taught including Social Studies, Mathematics and Science.

El Zein et al. Informal measure of reading comprehension.

(2016)

Lindeblad Standardised measures of word reading, sentence reading,

et al. (2016)

non-word reading, reading comprehension.

Schneider

et al. (2016)

Standardised measures of word reading, pseudoword reading, word spelling, pseudoword spelling, and word reading fluency.

Musti-Rao

et al. (2015)

Shannon

et al. (2015)

Tyler et al.

(2015)

Jere-Folotiya

et al. (2014)

Kamykowska

et al. (2014)

Larabee et al. Informal measures of phonics and letter-sound knowledge, (2014) reading speed, pseudoword reading speed, non-verbal abilities,
and receptive vocabulary.

Informal measures of sight word reading; standardised measures of reading fluency.

A norm- and criterion-referenced assessment of word knowledge analysing literary text, understanding author's craft, comprehensio strategies and constructing meaning, and analysing argument and evaluating text.

Standardised measures of reading accuracy, fluency and word recognition.

Standardised tests of orthographic awareness and spelling.

Standardised tests of phonics and letter-sound knowledge, word

words and pseudowords.

\section{Results}

Improved reading fluency and comprehension.

Phase I and II results showed a significant difference between experimental and contro groups (in favour of the experimental group) on measures of word reading, vocabulary, reading comprehension and listening comprehension. Experimental participants significantly outperformed control participants in the subject examinations.

All children's reading accuracy and fluency increased (the number of correct words read per minute) as a result of the intervention.

Phase 1: All groups improved significantly on all outcome measures. There was no difference among the performance of the three different intervention groups. Phase 2 : All groups improved significantly on all outcome measures. There was no difference among the performance of the three different intervention groups except that decoding accuracy showed greater improvement for the phoneme-level intervention group compared to the rime-level intervention group.

Children improved in reading fluency and comprehension as a result of the intervention.

The experimental group had significantly higher scores than the control group on measures of decoding, phonological awareness, naming speed, phonological short-term memory and executive loaded working memory.

Significant improvement was found for both GraphoGame and classroom instruction interventions. GraphoGame intervention led to greater improvement than classroom instruction intervention.

Significant differences in favour of the intervention group for all GraphoLearn in-game measures. No significant differences between groups on standardised measures. Both groups showed improvement on all measures from pre-test to post-test.

Both treatment groups had statistically significantly higher word reading, sentence reading and spelling skills than the control group at post-test follow-up 1 and 2 years later.

No significant difference in the gains on Spanish pseudoword and real word reading accuracy and fluency between the intervention and control conditions. No significan difference in gains on English reading.

Reading fluency and comprehension improved for practised and novel passages during intervention and on the 2 week and 1 month follow-ups.

Significant effects for reading comprehension and accuracy but not for rate. The intervention group in school 2 (two sessions per week) demonstrated significantly larger gains in reading accuracy and comprehension than the group in school 1 (one session per week).

Grapho-syllabic training led to improved performance in written word recognition (as well as phonological awareness and decoding). Comprehension training improved listening and reading comprehension (and vocabulary and comprehension monitoring).

Reading skills improved significantly in intervention group compared to control groups.

Learners in the intervention scored significantly higher than control learners on vocabulary, reading, phoneme segmentation and blending fluency. Both groups performed similarly for word reading, and listening comprehension.

No intervention effects were found; intervention and control participants showed no significant differences in any areas.

Intervention improved the reading fluency of the learners.

Intervention effects were found for pseudoword reading and reading fluency.

Intervention group made significant gains in reading and listening comprehension compared to the control group. No significant difference between the groups on other measures. Intervention group outperformed children in the control group in the exams (small effect size).

Teacher-directed instruction was more effective than iPad instruction for increasing the accuracy of responses.

Significant improvement in reading and reading comprehension between pre-test and post-test measures. At a 1-year follow-up, the children in the intervention group had developed reading skills at a rate equivalent to typically developing children.

Intervention group improved significantly more than children in the control group on measures of word spelling, non-word spelling, and word fluency. Significant effects were not detected for non-word and real word reading but there were non-significant differences favouring learners in the treatment group.

Improvements in sight word reading; gains not achieved for oral reading fluency.

The intervention group showed significantly greater gains on the assessment than the contro group. A moderate effect size was found. The programme had a positive impact on learner's reading achievement.

Significant improvements in favour of the intervention group for reading accuracy but not for reading fluency or word recognition.

Intervention improved the spelling of participants (intervention learners significantly outperformed control learners).

No differences between the group who received GraphoGame intervention and a Maths intervention on study outcomes; no intervention effect.

No difference between iPad instruction and instruction with typical materials on letter knowledge and word reading. Impact of iPad intervention on reading performance was
mixed. 
TABLE 3-A1 (Continues...): Outcome measures and results of the studies included in the information and communication technology-based reading intervention literature review.

\begin{tabular}{|c|c|}
\hline Study & Outcome measures \\
\hline $\begin{array}{l}\text { Lysenko and } \\
\text { Abrami } \\
\text { (2014) }\end{array}$ & $\begin{array}{l}\text { Standardised measures of vocabulary, reading comprehension, } \\
\text { listening comprehension and writing. }\end{array}$ \\
\hline $\begin{array}{l}\text { Rivera et al. } \\
\text { (2014) }\end{array}$ & Informal measure of expressive vocabulary. \\
\hline $\begin{array}{l}\text { Walcott et al. } \\
\text { (2014) }\end{array}$ & $\begin{array}{l}\text { Standardised measures of reading fluency and phoneme } \\
\text { segmentation and researcher-developed observational measures } \\
\text { for attention-to-task. }\end{array}$ \\
\hline
\end{tabular}

Cullen et al. Informal measure of sight word reading.

Ecalle et al. Standardised assessment of word reading for study 1 . Standardised

(2013) assessment of silent word recognition, aloud word reading, and reading comprehension for study 2 .

Fälth et al. Standardised measures of sight word reading, word reading,

(2013) pseudoword reading, phonological awareness (deletion) and reading comprehension.

Heikkilä et al. Non-standardised measures of syllable reading, pseudoword (2013) reading, passage reading and rapid automatised naming.

Kyle et al. Standardised measures of reading, spelling, and phonological (2013) awareness.

Potocki et al. Non-standardised measures of listening comprehension, reading (2013) comprehension and comprehension monitoring; standardised measure of receptive vocabulary.

Results

Intervention resulted in significant gains in vocabulary and reading comprehension but not listening comprehension or writing.

Expressive vocabulary for the target words improved in English and Spanish as a result of the shared story reading, which contained vocabulary instruction.

For study 1 and 2, all participants had improvements in oral reading fluency, phoneme segmentation, and attention-to-task relative to their baseline functioning.

Intervention resulted in participants acquiring all sight words and maintenance effects were present 4 weeks after intervention.

Study 1: children from the grapho-syllabic training group significantly outperformed children from the grapho-phonemic training and control group in word reading. Study 2: children in the grapho-syllabic and grapho-phonemic training groups both showed gains on silent word recognition, word reading and reading comprehension.

Statistically significant improvements were made for all groups on all measures. Typically developing readers made the greatest improvements followed by (in order from highest to lowest gains) the combined treatment group, the word phonological group, the comprehension group, and the regular special instruction group.

Intervention children read trained syllables significantly faster than the control group. There were no significant differences between the groups' reading speed for untrained syllables; there were no differences between the groups on passage reading speed.

Both games lead to improvements in reading, spelling and phonological awareness; gains were maintained at a 4-month follow-up.

The experimental group progressed more between the pre-test and the two post-tests sessions and the difference between the groups was significant at the second post-test (11 months after the training phase). For vocabulary and comprehension monitoring significant difference between the experimental group and the control group was only present at the first post-test.

Ponce et al. Standardised measure of reading comprehension.

(2012)

Chambers Standardised measures of letter knowledge, word reading,

et al. (2011) pseudoword reading, and reading comprehension.

The intervention group performed significantly better than the control group on reading comprehension.

For Grade 1, the intervention group outperformed the control group on all three reading measures. For Grade 2, there was no significant difference between the intervention and control groups.

The three intervention groups improved their reading skills at least as much as the comparison groups.

Gustafson Standardised measures of sight word reading, word decoding et al. (2011) pseudoword reading, reading comprehension and passage comprehension.

Kim et al. Standardised measures of reading comprehension, spelling, (2011) vocabulary, reading accuracy and reading rate.

Saine et al. Standardised measures of letter knowledge, reading accuracy, (2011) fluency and spelling.

Yaw et al. Informal measures: Dolch sight word lists.

(2011)

Kim et al.

Standardised measures of sight word reading, vocabulary, reading (2010) rate.

A significant difference between the intervention and control groups on measures of vocabulary and reading comprehension.

Children in the computer-based intervention group improved during Grade 1 and continued to progress similarly in the follow-ups conducted 12 months and 16 months after the intervention had ended. The overall gains in the computer-assisted intervention were significant for letter knowledge, decoding, accuracy, fluency and spelling.

Intervention improved sight word reading significantly compared to multiple baseline measures.

No significant difference between the reading performance of the intervention and control groups on post-test measures of sight word reading, phonetic decoding, vocabulary and comprehension. Children in the intervention group performed significantly higher on measures of reading fluency (accuracy and rate) but this phenomenon was only found for children in Grade 4.

Savage et al. Informal measure of grapheme-phoneme knowledge. Standardised

(2010) measures of listening comprehension, word reading, word

There were significant differences in students' reading outcomes across the intervention groups. meaning, vocabulary, sentence comprehension, passage comprehension, spelling, pseudoword reading, phonological awareness, and arithmetic.

Torgesen Standardised measures of word accuracy and fluency, phonemic et al. (2010) decoding accuracy and fluency, text reading accuracy and fluency, decoding accuracy and fluency, text reading accuracy and fluency, reading com
and spelling.

Ecalle et al. Non-standardised tests of word recognition, reading words aloud,

(2009) and word spelling.

Macaruso Standardised measures of single word reading, pseudoword $\begin{array}{ll}\text { and Rodman } & \text { reading, reading fluency, reading vocabulary, reading } \\ \text { (2009) } & \text { comprehension, listening comprehension, and spelling. }\end{array}$

Savage et al. Standardised measures of letter-sound knowledge, listening (2009) comprehension, word reading, word meaning, sentence comprehension, passage comprehension, reading fluency, pseudoword reading, and phonological awareness (deletion, blending).

Reading outcomes were slightly stronger in the group that received the Lindamood Phoneme Sequencing Program for Reading, Spelling, and Speech intervention compared to the group that received the read-write-type intervention, but this finding was not statistically significant.

The treatment group significantly outperformed the control group at all three post-tests on measures of word recognition, reading words aloud and word spelling. Large treatment effects were observed.

Intervention learners showed significantly larger gains than control learners on measures of decoding skills. Intervention learners showed a trend towards greater gains than control learners on word reading. Both groups had improved reading comprehension.

For the analytic phonics programme, there were significant improvements in lette knowledge. For the synthetic phonics programme, there were significant improvements phonological awareness, listening comprehension, reading comprehension, and reading fluency. Both interventions had a significant impact on literacy at post-test and follow-up.

Note: Papers are ordered chronologically by year and alphabetically within years. Please see the full reference list of this article, Dean, J., Pascoe, M. \& Le Roux, J., 2021, 'Information and communication technology reading interventions: A scoping review', Reading \& Writing 12(1), a294. https://doi.org/10.4102/rw.v12i1.294, for more information. 